\title{
Endogenous synthesis of rumenic acid in humans and cattle*
}

\author{
B. Niwińska ${ }^{1}$ \\ National Research Institute of Animal Production, \\ Department of Animal Nutrition and Feed Science \\ 32-080 Balice, Poland
}

(Received 17 June 2009; revised version 1 February 2010; accepted 9 May 2010)

\begin{abstract}
Recent results of biomedical studies suggest that rumenic acid (RA), the major isomer of conjugated octadecadienoic acids (CLA), appears to have beneficial health effects in humans. The major source of RA in the human diet is milk and beef fat, but average intake is too low to exhibit a health-protective effect. In light of current studies, the total amount of RA available to humans also depends on the endogenous synthesis of RA through $\Delta^{9}$-desaturase activity with trans-vaccenic acid (VA) as the substrate. The results of experiments suggest that the endogenous synthesis of RA has positive effects on human health. The enrichment in VA and RA of bovine fat through the diet is well documented in the literature. Current research has demonstrated that $\Delta^{9}$ - desaturase is responsible for more than $80 \%$ of RA in milk and beef fat and that the enzyme activity is affected by non-dietary factors. This review presents the current state of knowledge about the influences of breeds, stage of lactation, type of tissues, enzyme gene polymorphisms and interactions with other genes, nutrients and hormones at tissue level on the endogenous synthesis of RA in cattle.
\end{abstract}

KEY WORDS: $\Delta^{9}$ - desaturase, trans-vaccenic acid, rumenic acid, human, cattle

\section{INTRODUCTION}

Rumenic acid (RA) is a common name for cis-9, trans-11-octadecadienoic acid, the major isomer of conjugated octadecadienoic acids (CLA) found in the milk and meat of ruminants (Kramer et al., 1998). The endogenous synthesis of RA is catalyzed by $\Delta^{9}$-desaturase, a membrane-bound enzyme of the endoplasmic

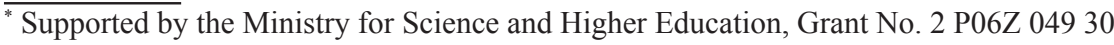

${ }^{1}$ Corresponding author: e-mail: niwb@izoo.krakow.pl
} 
reticulum (EC 1.14.19.1; referred to as stearoyl-CoA 9-desaturase) that introduces a double bond in fatty acyl-coenzyme $A$ at the delta 9 position in a large spectrum of fatty acids (Ntambi, 1999). The substrate of RA synthesis is trans-vaccenic acid (trans-11 octadecenoic acid; VA), the intermediate product in the biohydrogenation of dietary oleic, linoleic and linolenic acids in the rumen (Jenkins et al., 2008) and of linoleic acid in the human intestine (McIntosh et al., 2009).

The human anticarcinogenic, anti-inflammatory, and potential antiatherogenic effects of dietary RA have been widely presented (Ip et al., 1999; Wahle et al., 2004; Parodi, 2005; Lee, 2008). The major source of RA in the human diet is milk and beef fat, but the mean intake of RA is too low. In light of the study by Ritzenthaler et al. (2001), the mean intake of RA is around $193 \mathrm{mg} / \mathrm{d}$ for men and $140 \mathrm{mg} / \mathrm{d}$ for women. According to the authors' suggestion, the intake must be $620 \mathrm{mg} / \mathrm{d}$ for men and $441 \mathrm{mg} / \mathrm{d}$ for women to exhibit a protective effect on health. Human requirements for RA may be partially covered by endogenous synthesis. $\Delta^{9}$-desaturase activity is responsible for from 10 to $19 \%$ of RA in serum, cell membranes and milk lipids (Turpeinen et al., 2002; Mosley et al., 2006a). Enrichment of the functional properties of bovine fat based on RA and VA contents is, nonetheless, still warranted.

Information about the possibility of controlling the production of VA and RA in the rumen and, consequently, modifying the composition of fatty acids in milk and beef fat through the diet is well described in the literature (Sejrsen et al., 2007; Bharathan et al., 2008; Hess et al., 2008; Jenkins et al., 2008; Duckett et al., 2009). Research undertaken over the past decade has certainly made it clear that the composition of fatty acids in bovine fat also depends on non-dietary factors affecting $\Delta^{9}$-desaturase activity. Endogenous synthesis via $\Delta^{9}$ - desaturase is responsible for more than $80 \%$ of RA in milk and beef fat (Mosley et al., 2006b; Pavan and Duckett, 2007). Although many results have confirmed the feeding impact, the non-dietary factors have received little attention.

It is the objective of this paper to give a brief overview of the endogenous synthesis of rumenic acid in humans and in cattle, as illustrated by information from the literature.

\section{ENDOGENOUS SYNTHESIS OF RA IN HUMANS}

The role of $\Delta^{9}$-desaturase in conversion of VA to RA in humans was confirmed for the first time in the study by Turpeinen et al. (2002). The authors found that an increase in the consumption of VA was associated with a linear increase in the serum concentration of both fatty acids. The concentration of VA increased by 194,407 and $620 \%$ and that of RA, by 50,169 and $198 \%$ above baseline 
when diets were supplemented with 1.5 vs 3.0 vs $4.5 \mathrm{~g}$ of VA/d. The conversion varied from $0 \%$ in a subject with a low intake of VA to over 30\% in a subject with a high intake of VA. The mean conversion rate was estimated to be $19 \%$. This conversion value was confirmed in red blood cell membrane FA composition in humans receiving a diet supplemented with $3 \mathrm{~g} / \mathrm{d}$ of VA (Kuhnt et al., 2006). The $\Delta^{9}$-desaturase activity was studied by Mosley et al. (2006 a) in an in vivo experiment with four lactating women receiving $2.5 \mathrm{mg}$ of ${ }^{13} \mathrm{C}$-labeled VA/kg body weight. The ${ }^{13} \mathrm{C}$-labeled product of endogenous synthesis was found in serum triglycerides, cholesterol esters, phospholipids and in milk lipids. The authors reported that nearly $10 \%$ of RA in human milk originated from endogenous desaturation, despite the considerable individual variation, which may be attributed to differences in diet, physiological state or genetic potential of humans. These observations confirm that endogenously synthesized RA is detectable in human serum, cell membranes and milk lipids.

In recent years, the health risks associated with consumption of diets containing VA have been analysed in studies with animal models, in tissue culture systems, and in clinical research. Studies with animal models used selected species and strains of animals in which an induced pathological process corresponded to the same disease in humans. The purpose of this part of the article is a brief characterization of the current scientific information about human health effects of the endogenous synthesis of RA.

Anticarcinogenic effects. The anticarcinogenic effects of endogenous synthesis of RA catalyzed by $\Delta^{9}$-desaturase was first found in the study by Banni et al. (2001) with rats that were treated with a chemical carcinogen. The authors demonstrated that feeding a diet with $2 \%$ VA was accompanied by a nearly $50 \%$ reduction in the number of premalignant lesions in the rat mammary gland. This positive effect was confirmed by Lock and Bauman (2004), who additionally showed that if the activity of $\Delta^{9}$-desaturase was inhibited, the anticarcinogenic effect of VA was blocked. The authors suggested that the anticancer properties of VA are due to the conversion of VA to RA. Numerous health benefits have been confirmed in studies with human tumor cell cultures incubated with VA. The results demonstrated inhibition of growth and induction of apoptosis of human breast and colon cancer cells (Miller et al., 2003) and changes in the composition of cellular lipids in the Caco-2 cell line, a model of human epithelial colorectal adenocarcinoma (Reynolds et al., 2008).

Immunomodulatory effects. The relationship between immune function and dietary VA and RA was analysed in a study with C57BL/6 mice. RA and VA reduced circulating allergen-specific immunoglobulin levels, together with reductions in bronchoalveolar lavage fluid of cytokines regulating eosinopoiesis and eosinophil 
maturation in mice sensitized by intraperitoneal injection of ovalbumin (Kanwar et al., 2007). These fatty acids significantly inhibited epithelial cell hypertrophy, goblet cell metaplasia, and mucus hypersecretion when fed together, but these effects were not found when VA and RA were fed alone.

Reduction in metabolic disorders. The relationship between dietary VA and metabolic disorders was analysed in a study with JCR:LA-cp rats genetically predisposed to develop severe insulin resistance with hyperinsulinaemia, hyperlipidaemia and obesity, a unique animal model exhibiting all aspects of human disease processes such as metabolic syndrome. The incorporation of $1.5 \%$ of VA in the diet of JCR:LA-cprats decreased the concentration of serum immunoregulatory cytokines, normalized production of pro-inflammatory mesenteric lymphocytes in obese rats to levels similar to those seen in lean rats, and fasting triglyceride concentrations decreased (by nearly 40\%) in VA-treated obese rats relative to obese rats fed the control diet (Wang et al., 2008; Blewett et al., 2009). The authors concluded that VA may have substantial hypotriglyceridaemic benefits under conditions of dyslipidaemia. The significant reductions in serum cholesterol and triglyceride levels were presented in an animal model study with VA-treated low density lipoprotein (LDL) receptor deficient $\left(\mathrm{LDLr}^{--}\right)$mice (Bassett et al., 2010). In studies with humans, an increase in VA intake resulted in compositional changes of blood lipids (Tholstrup et al., 2006). In men receiving VA-enriched butter $(3.6 \mathrm{~g} \mathrm{VA} / \mathrm{d}), 6 \%$ lower plasma total cholesterol and 9\% lower plasma LDL concentrations compared with those found in men receiving a diet with conventional butter were found. Additionally, intake of a diet high in VA resulted in an increase in the RA in plasma lipid classes: cholesterol esters, phospholipids and triacylglycerols.

The results of studies cited above demonstrate the positive effects on human health of endogenous synthesis of RA; however, it was not clear whether these effects were attributed to $\Delta^{9}$-desaturase activity in conversion of VA to RA or to VA itself and also to the increase in the concentration of synthesized RA. It seems that further studies should clarify this mechanism.

\section{ENDOGENOUS SYNTHESIS OF RA IN CATTLE}

Until the last decade of the $20^{\text {th }}$ century, it was generally assumed that the uniqueness of CLA in food products derived from ruminants relates to the incomplete biohydrogenation of dietary unsaturated fatty acids in the rumen (Parodi, 1977). At the end of the 1990s, Griinari et al. (1997) noted that the content of RA in milk fat was not closely associated with rumen production and hypothesized that the 
amount of RA in milk fatty acids (FA) might be influenced by the de novo synthesis in tissues through the existence of an active pathway for endogenous synthesis via $\Delta^{9}$-desaturase. This suggestion has been examined in numerous experiments analysing changes in milk fat FA composition depending on the diet composition or on postruminal infusion of VA, many of them using infusion of sterculic oil as a source of cyclopropene fatty acid, an inhibitor of $\Delta^{9}$-desaturase. The enzyme activity was characterized by many indicators. The basic ones are: the VA and RA content in total FA, RA-desaturase index, or $\Delta^{9}$-desaturase expression based on tissue $\Delta^{9}$-desaturase mRNA concentration. The RA-desaturase index was calculated from the product (RA)-substrate (VA) relationship, defined as the ratios product/ substrate, or substrate/product, or product/(substrate + product). Research findings demonstrated the role of endogenous synthesis of RA in cattle.

Origin of RA in milk fat. Comparing fatty acid pairs that represented the substrate/ product ratio as an indicator of $\Delta^{9}$-desaturase activity in an experiment involving a 3-day abomasal infusion of VA and sterculic oil, Griinari et al. (2000) determined that nearly $64 \%$ of the RA in milk fat was of endogenous origin. This significant contribution of endogenous synthesis of RA to milk FA was soon confirmed. Comparison of the amounts of RA and VA flowing through the duodenum with the daily yield of these fatty acids in milk fat showed that from 82 to $97 \%$ of milk RA was synthesized endogenously (Lock and Garnsworthy, 2002; Piperova et al., 2002; Loor et al., 2005). The results of research using sterculic oil have also confirmed that from 78 to $91 \%$ of the RA came from desaturase activity on VA (Corl et al., 2001; Kay et al., 2004). The direct assessment of $\Delta^{9}$-desaturase activity was estimated using tracer methodology. In an experiment with cows abomasally infused with ${ }^{13} \mathrm{C}$-labeled VA, Mosley et al. (2006b) estimated that $83 \%$ of milk fat RA originated from VA, with the mammary gland being the primary site of $\Delta^{9}$ desaturase activity. The role of the mammary gland has been confirmed both in studies describing the greater concentrations of VA relative to RA in plasma lipid in comparison with this relationship found in milk fat (Bharathan et al., 2008) and in studies estimating mammary uptake of substrates from the bloodstream (Shingfield et al., 2007; Glasser et al., 2008). The cited studies reported that the contribution of mammary desaturated VA to milk RA yield ranged from 71 to $100 \%$, and 21 to $29 \%$ of the additional VA uptake in lipid-supplemented diets was desaturated in the udder. The presented results indicate clearly that the principal source of RA in milk fat is endogenous synthesis in the mammary gland.

Origin of RA in beef fat. The potential of de novo synthesis of RA has also been examined in tissues other than the mammary gland. It was estimated, based on the ratio of VA to RA in abomasal digesta vs tissue sample, that nearly $86 \%$ of the total RA in the Longissimus dorsi muscle were synthesized endogenously 
and over $80 \%$, in the adipose tissue of Angus $\times$ Hereford heifers and Angus steers (Gillis et al., 2003; Pavan and Duckett, 2007). When comparing $\Delta^{9}$-desaturase activity in different tissues of Angus steers, Archibeque et al. (2005) found the highest enzyme activity in intestinal mucosal cells, with average interfasicular and subcutaneous adipose cells, and the lowest enzyme activity in liver (126.7, 74.3, 36.7 and $12.7 \mathrm{nmol}$ of $\Delta^{9}$-desaturase $\times \mathrm{g}$ tissue ${ }^{-1} / 7 \mathrm{~min}^{-1}$, respectively). The results of the same experiment, in accordance with suggestions of Bauman and Griinari (2001) and Scholljegerdes et al. (2007), pointed to a close relationship between concentrations of RA and of VA in circulation and enzyme activity in tissues.

In summary it may be stated that endogenous synthesis represents the major source of rumenic acid in milk and beef fat.

\section{NON-DIETARY FACTORS OF $\Delta^{9}$ - DESATURASE ACTIVITY IN CATTLE}

Research undertaken over the past decade has made it clear that the endogenous synthesis of rumenic acid depends both on the quantity of VA originating from rumen fermentation and on non-dietary factors affecting enzyme activity. The purpose of this part of the article is a brief characterization of non-dietary factors based on current scientific reports.

Breed effects. When comparing enzyme activity among breeds of cattle, higher activity was observed in Holstein cows in comparison with Jersey (Beaulieu and Palmquist, 1995) and Brown Swiss cows (Kelsey et al., 2003). This relationship has been confirmed in subsequent investigations by Soyeurt et al. $(2006,2008)$, who found statistically significant differences also between Holsteins and dual purpose Belgian Blue, Jersey, Montbeliarde, non-Holstein Meuse-Rhine-Yssel type Redand-White breeds. Like the activity of $\Delta^{9}$ - desaturase in the mammary glands, its activity in the fatty tissue varies among breeds of cattle. In adipose tissue, higher enzyme activity (by nearly 20\%) and higher concentration of $\Delta^{9}$ - desaturase mRNA (nearly 70\%) were found in Wagyu than in Angus steers (Chung et al., 2007).

Enzyme genetic parameter effects. Recently, particular attention has been focused on factors supported by the results of functional genomics research. The delta-9-desaturase-1 locus (GenBank accession no. AY241932) has been mapped on bovine chromosome 26 (Chung et al., 2000; Lengi and Corl, 2007). It has been reported that a nucleotide polymorphism with 2 alleles (A and V) in the fifth exon of the gene was associated with the monounsaturated fatty acid content in total milk fatty acids (Taniguchi et al., 2004). This relationship is of particular interest, but the presented results were not consistent. According to Mele et al. (2009), milk of AA genotype Italian Holstein Friesian cows was characterized by a significantly 
higher content of total monounsaturated fatty acids (nearly $10 \%$ ) when compared with the VV genotype. In this study, the AA genotype was associated with a higher content of VA and RA and higher value of the RA-desaturation index, but the differences did not reach significance. A significant positive effect of the AA genotype on VA content in milk fat compared with the VV genotype was confirmed in Dutch Holstein-Friesian heifers but, at the same time, a lower content of RA and lower value of RA-desaturation index was characteristic of cows with the AA genotype (Schennink et al., 2008). These results suggest that it is possible to change milk FA composition by genetic selection.

Other gene, nutrient, and hormone interaction effects. No positive effects of $\Delta^{9}$-desaturase AA genotype on fatty acid composition and the RA-desaturation index in Canadian Jersey cows (Kgwatalala et al., 2009) and in Piedmontese and Valdostana dairy breeds were noted (Moioli et al., 2007). These authors suggested that the activity of this enzyme is not merely affected by gene polymorphism, but also by interaction with other genes. These dependencies have been confirmed in research carried out in recent times. The regulation of $\Delta^{9}$-desaturase gene expression takes place at multiple levels, including transcription, translation, protein turnover and enzyme activity (Bionaz and Loor, 2008). The inhibiting effect of oleic acid on the gene transcription rate in a mammary epithelial cell line has been described (Keating et al., 2006), as have been the modifying effects of RA and the trans-10, cis-12 isomer of CLA on enzyme post-translational synthesis (Eberle et al., 2004; Harvatine and Bauman, 2006; Sampath and Ntambi, 2006) and the interference of n-3 PUFA with the function of transcriptional activators (Waters et al., 2009). The regulation of expression of the $\Delta^{9}$-desaturase gene is also activated by the hormonal system. Stimulating effects of insulin and inhibiting effects of leptin on $\Delta^{9}$-desaturase mRNA synthesis were noted (Keating et al., 2006). At present, the molecular mechanisms by which dietary fatty acids and hormones regulate $\Delta^{9}$-desaturase activity and enzyme expression are not completely established, but the cited results illustrate the existence of interactions between nutrients and the gene at the expression level.

Lactation stage effects. With regard to the impact of lactation stage on milk FA composition, Kgwatalala et al. (2009) found that in early lactation (before 100 d), Canadian Jersey cows produced milk fat with a significantly lower RA content than at a later (above $200 \mathrm{~d}$ ) stage, but the content of VA was unchanged. Consequently, the estimated RA-desaturase index, calculated as the RA/ (RA+VA) ratio, was lower during the early stage of lactation compared with the indexes estimated in the subsequent stages. These results are consistent with Bionaz and Loor (2008), who indicated that the concentration of $\Delta^{9}$ - desaturase mRNA in mammary tissue in Holstein cows peaked (over 40 -fold) at $60 \mathrm{~d}$ post- 
partum and decreased during the next 180 days, while expression of genes with recognized roles in mammary lipid metabolism followed the lactation curve. However, the same results showed that despite the high expression of $\Delta^{9}$ - desaturase, the correlation between mRNA concentration and both milk FA composition and desaturase indexes was statistically non-significant. The authors suggested that this discrepancy resulted from a large number of factors influencing milk fatty acid composition.

Age effects. There are few observations on age-related changes. A nearly 3 -fold increase in $\Delta^{9}$-desaturase mRNA levels in the Longissimus dorsi muscle of Korean Hanwoo and Angus steers was reported between 6 and 12 months of age, followed by a slight decline between 18 and 30 months (Lee et al., 2005; Chung et al., 2007). Hausman et al. (2009) suggested that the age-related differences are associated with adipocyte development processes.

The non-dietary factors of $\Delta^{9}$-desaturase activity listed above are important in an effective strategy for enrichment of bovine fat in RA.

\section{CONCLUSIONS}

Endogenous synthesis via $\Delta^{9}$-desaturase enzyme activity is an important source of rumenic acid in both humans and cattle. In humans, this process is linked with beneficial health effects, which may be attributed to $\Delta^{9}$-desaturase activity in conversion of trans-vaccenic acid to rumenic acid or to trans-vaccenic acid itself and also to the increase in the concentration of synthesized rumenic acid.

In cattle, this process is related to rumenic acid contents in milk and beef fat. The enrichment of bovine fat in rumenic acid should take into account the nondietary factors modulating the activity of $\Delta^{9}$-desaturase: breed, stage of lactation, type of tissues, enzyme gene polymorphisms, and, additionally, interaction with other genes, nutrients and hormones at the tissue level.

\section{REFERENCES}

Archibeque S.L., Lunt D.K., Gilbert C.D., Tume R.K., Smith S.B., 2005. Fatty acid indices of stearoylCoA desaturase do not reflect actual stearoyl-CoA desaturase enzyme activities in adipose tissues of beef steers finished with corn-, flaxseed-, or sorghum-based diets. J. Anim. Sci. 83, 11531166

Banni S., Angioni E., Murru E., Carta G., Melis M.P., Bauman D., Dong Y., Ip C., 2001. Vaccenic acid feeding increases tissue levels of conjugated linoleic acid and suppresses development of premalignant lesions in rat mammary gland. Nutr. Cancer 41, 91-97 
Bassett C.M.C., Edel A.L., Patenaude A.F., McCullough R.S., Blackwood D.P., Chouinard P.Y., Paquin P., Lamarche B., Pierce G.N., 2010. Dietary vaccenic acid has antiatherogenic effects in LDLr $^{-/}$mice. J. Nutr. 140, 18-24

Bauman D. E., Griinari J.M., 2001. Regulation and nutritional manipulation of milk fat: low-fat milk syndrome. Livest. Prod. Sci. 70, 15-29

Beaulieu A.D., Palmquist D.L., 1995. Differential effects of high fat diets on fatty acid composition in milk of Jersey and Holstein cows. J. Dairy Sci. 78, 1336-1344

Bharathan M., Schingoethe D.J., Hippen A.R., Kalscheur K.F., Gibson M.L., Karges K., 2008. Conjugated linoleic acid increases in milk from cows fed condensed corn distillers solubles and fish oil. J. Dairy Sci. 91, 2796-2807

Bionaz M., Loor J. J., 2008. Gene networks driving bovine milk fat synthesis during the lactation cycle. BMC Genomics 9, 366-387

Blewett H. J., Gerdung C.A., Ruth M. R., Proctor S.D., Field C.J., 2009. Vaccenic acid favourably alters immune function in obese JCR:LA- cp rats. Brit. J. Nutr. 16, 1-11

Chung M., Ha S., Jeong S., Bok J., Cho K., Baik M., Choi Y., 2000. Cloning and characterization of bovine stearoyl CoA desaturase1 cDNA from adipose tissues. Biosci. Biotechnol. Biochem. 64, $1526-1530$

Chung K. Y., Lunt D. K., Kawachi H., Yano H., Smith S., B. 2007. Lipogenesis and stearoyl-CoA desaturase gene expression and enzyme activity in adipose tissue of short- and long-fed Angus and Wagyu steers fed corn- or hay-based diets. J. Anim. Sci. 85, 380-387

Corl B. A., Baumgard L. H., Dwyer D. A., Griinari J. M., Phillips B. S., Bauman D. E., 2001. The role of $\Delta^{9}$-desaturase in the production of cis-9, trans-11 CLA. J. Nutr. Biochem. 12, 622-630

Duckett S.K., Pratt S.L., Pavan E., 2009. Corn oil or corn grain supplementation to steers grazing endophyte-free tall fescue. II. Effects on subcutaneous fatty acid content and lipogenic gene expression. J. Anim. Sci. 87, 1120-1128

Eberle D., Hegarty B., Bossard P.F., Foufelle F., 2004. SREBP transcription factors: master regulators of lipid homeostasis. Biochimie 86, 839-848

Gillis M.H., Duckett S.K., Sackmann J.R., Keisler D.H., 2003. Effect of rumen-protected conjugated linoleic acid (CLA) or linoleic acid on leptin and CLA content of bovine adipose depots. J. Anim. Sci. 81, Suppl. 2, 12 (Abstr.)

Glasser F., Ferlay A., Doreau M., Schmidely P., Sauvant D., Chilliard Y., 2008. Long-chain fatty acid metabolism in dairy cows: A meta-analysis of milk fatty acid yield in relation to duodenal flows and de novo synthesis. J. Dairy Sci. 91, 2771-2785

Griinari J.M., Chouinard P.Y., Bauman D.E., 1997. Trans fatty acid hypothesis of milk fat depression revised. Cornell University, Ithaca, NY. In: Proceedings of Cornell Nutrition Conference Feed Manufacture, pp. 208-216

Griinari J.M., Corl B.A., Lacy S.H., Chouinard P.Y., Nurmela K.V., Bauman D.E., 2000. Conjugated linoleic acid is synthesized endogenously in lactating dairy cows by delta(9)-desaturase. J. Nutr. $130,2285-2291$

Harvatine K.J., Bauman D.E., 2006. SREBP1 and thyroid hormone responsive Spot 14 (S14) are involved in the regulation of bovine mammary lipid synthesis during diet-induced milk fat depression and treatment with CLA. J. Nutr. 136, 2468-2474

Hausman G.J., Dodson M.V., Ajuwon K. et al., 2009. Board-invited review: The biology and regulation of preadipocytes and adipocytes in meat animals. J. Anim. Sci. 87, 1218-1246

Hess B.W., Moss G.E., Rule D.C., 2008. A decade of developments in the area of fat supplementation research with beef cattle and sheep. J. Anim. Sci. 86, E Suppl., E188-E204 
Ip C., Banni S., Angioni E., Carta G., McGinley J., Thompson H.J., Barbano D., Bauman D., 1999. Conjugated linoleic acid-enriched butter fat alters mammary gland morphogenesis and reduces cancer risk in rats. J. Nutr. 129, 2135-2142

Jenkins T.C., Wallace R.J., Moate P.J., Mosley E.E., 2008. Board-invited review: Recent advances in biohydrogenation of unsaturated fatty acids within the rumen microbial ecosystem. J. Anim. Sci. $86,397-412$

Kanwar R.K., Macgibbon R.K., Black P.N., Kanwar J.R., Rowan A., Vale M., Krissansen G.W., 2007. Bovine milk fat enriched in conjugated linoleic and vaccenic acids attenuates allergic airway disease in mice. Clin. Exp. Allergy 38, 208-218

Kay J.K., Mackle T.R., Auldist M.J., Thomson N.A., Bauman D.E., 2004. Endogenous synthesis of cis-9, trans-11 conjugated linoleic acid in dairy cows fed fresh pasture. J. Dairy Sci. 87, 369-378

Keating A.F., Kennelly J.J., Zhao F.Q., 2006. Characterization and regulation of the bovine stearoylCoA desaturase gene promoter. Biochem. Biophys. Res. Commun. 344, 233-240

Kelsey J.A., Corl B.A., Collier R.J., Bauman D.E., 2003. The effect of breed, parity, and stage of lactation on conjugated linoleic acid (CLA) in milk fat from dairy cows. J. Dairy Sci. 86, 25882597

Kgwatalala P.M., Ibeagha-Awemu E.M., Mustafa A.F., Zhao X., 2009. Influence of stearoyl-coenzyme A desaturase 1 genotype and stage of lactation on fatty acid composition of Canadian Jersey cows. J. Dairy Sci. 92, 1220-1228

Kramer J.K.G., Parodi P.W., Jensen R.G., Mossoba M.M., Yurawecz M.P., Adlof R.O., 1998. Rumenic acid: a proposed common name for the major conjugated linoleic acid isomer found in natural products. Lipids 33, 835

Kuhnt K., Kraft J., Moeckel P., Jahreis G., 2006. Trans-11-18:1 is effectively delta-9-desaturated compared with trans-12-18:1 in humans. Brit. J. Nutr. 95, 752-761

Lee S.H., Yoon D.H., Choi N.J., Hwang S.H., Cheong E.Y., Oh S.J., Cheong I.C., Lee C.S., 2005. Developmental relationship of unsaturated fatty acid composition and stearoyl-CoA desaturase mRNA level in Hanwoo steers' muscle. Asian-Austr. J. Anim. Sci. 18, 562-566

Lee Y., 2008. Isomer specificity of conjugated linoleic acid (CLA): 9E,11E-CLA. Nutr. Res. Practice $2,4,326-330$

Lengi A.J., Corl B.A., 2007. Identification and characterization of a novel bovine stearoyl-CoA desaturase isoform with homology to human SCD5. Lipids 42, 499-508

Lock A.L., Bauman D.E., 2004. Modifying milk fat composition of dairy cows to enhance fatty acids beneficial to human health. Lipids 39, 1197-1206

Lock A.L., Garnsworthy P.C., 2002. Independent effects of dietary linoleic and linolenic fatty acids on the conjugated linoleic acid content of cow's milk. Anim. Sci. 74, 163-176

Loor J.J., Ferlay A., Ollier A., Ueda K., Doreau M., Chilliard Y., 2005. High-concentrate diets and polyunsaturated oils alter trans and conjugated isomers in bovine rumen, blood, and milk. J. Dairy Sci. 88, 3986-3999

McIntosh F.M., Shingfield K.J., Devillard E., Russell W.R., Wallace R.J., 2009. Mechanism of conjugated linoleic acid and vaccenic acid formation in human faecal suspensions and pure cultures of intestinal bacteria. Microbiology 155, 285-294

Mele M., Dal Zotto R., Cassandro M., Conte G., Serra A., Buccioni A., Bittante G., Secchiari P., 2009. Genetic parameters for conjugated linoleic acid, selected milk fatty acids, and milk fatty acid unsaturation of Italian Holstein-Friesian cows. J. Dairy Sci. 92, 392-400

Miller A., McGrath E., Stanton C., Devery R., 2003. Vaccenic acid (t11-18:1) is converted to c9,t11CLA in MCF-7 and SW480 cancer cells. Lipids 38, 623-632 
Moioli B., Contarini G., Avalli A., Catillo G., Orru` L., De Matteis G., Masoero G., Napolitano F., 2007. Short Communication: Effect of stearoyl-coenzyme A desaturase polymorphism on fatty acid composition of milk. J. Dairy Sci. 90, 3553-3558

Mosley E.E., McGuire M.K., Williams J.E., McGuire M.A., 2006a. Cis-9, trans-11 conjugated linoleic acid is synthesized from vaccenic acid in lactating women. J. Nutr. 136, 2297-2301

Mosley E.E., Shafii B., Moate P.J., McGuire M.A., 2006b. Cis-9, trans-11 conjugated linoleic acid is synthesized directly from vaccenic acid in lactating dairy cattle. J. Nutr. 136, 570-575

Ntambi J.M., 1999. Regulation of stearoyl-CoA desaturase by polyunsaturated fatty acids and cholesterol. J. Lipid Res. 40, 1549-1558

Parodi P.W., 1977. Conjugated octadecadienoic acids of milk fat. J. Dairy Sci. 60, 1550-1553

Parodi P.W., 2005. Dairy product consumption and the risk of breast cancer. J. Amer. Coll. Nutr. 24, S556-S568

Pavan E., Duckett S.K., 2007. Corn oil supplementation to steers grazing endophyte-free tall fescue. II. Effects on longissimus muscle and subcutaneous adipose fatty acid composition and stearoylCoA desaturase activity and expression. J. Anim. Sci. 85, 1731-1740

Piperova L.S., Sampugna J., Teter B.B., Kalscheur K.F., Yurawecz M.P., Ku Y., Morehouse K.M., Erdman R.A., 2002. Duodenal and milk trans octadecenoic acid and conjugated linoleic acid (CLA) isomers indicate that postabsorptive synthesis is the predominant source of cis-9 containing CLA in lactating dairy cows. J. Nutr. 132, 1235-1241

Reynolds C.M., Loscher C.E., Moloney A.P., Roche H.M., 2008. Cis-9, trans-11-conjugated linoleic acid but not its precursor trans-vaccenic acid attenuate inflammatory markers in the human colonic epithelial cell line Caco-2. Brit. J. Nutr. 14, 1-5

Ritzenthaler K.L., McGuire M.K., Falen R., Shultz T.D., Dasgupta N., McGuire M.A., 2001. Estimation of conjugated linoleic acid intake by written dietary assessment methodologies underestimates actual intake evaluated by food duplicate methodology. J. Nutr. 131, 1548-1554

Sampath H., Ntambi J.M., 2006. Regulation of gene expression by polyunsaturated fatty acids. Heart Metab. 32, 32-35

Schennink A., Heck J.M.L., Bovenhuis H.W., Visker M.H.P., van Valenberg H.J.F., van Arendonk J.A.M., 2008. Milk fatty acid unsaturation: Genetic parameters and effects of stearoyl-CoA desaturase (SCD1) and Acyl CoA: diacylglycerol acyltransferase 1 (DGAT1). J. Dairy Sci. 91, 2135-2143

Scholljegerdes E.J., Lake S.L., Weston T.R., Rule D.C., Moss G.E., Nett T.M., Hess B.W., 2007. Fatty acid composition of plasma, medial basal hypothalamus, and uterine tissue in primiparous beef cows fed high-linoleate safflower seeds. J. Anim. Sci. 85, 1555-1564

Sejrsen K., Bjørn T., Jensen S.K., 2007. Prospects of obtaining favourable fatty acid composition of cow's milk by feeding. J. Anim. Feed Sci. 16, Suppl. 1, 7-20

Shingfield K.J., Ahvenja S., Toivonen V., Vanhatalo A., Huhtanen P., 2007. Transfer of absorbed cis-9, trans-11 conjugated linoleic acid into milk is biologically more efficient than endogenous synthesis from absorbed vaccenic acid in lactating cows. J. Nutr. 137, 1154-1160

Soyeurt H., Dardenne P., Gillon A., Croquet C., Vanderick S., Mayeres P., Bertozzi C., Gengler N., 2006. Variation in fatty acid contents of milk and milk fat within and across breeds. J. Dairy Sci. $89,4858-4865$

Soyeurt H., Dehareng F., Mayeres P., Bertozzi C., Gengler N., 2008. Variation of $\Delta$-9-desaturase activity in dairy cattle. J. Dairy Sci. 91, 3211-3224

Taniguchi M., Utsugi T., Oyama K., Mannen H., Kobayashi M., Tanabe Y., Ogino A., Tsuji S., 2004. Genotype of stearoyl-CoA desaturase is associated with fatty acids composition in Japanese Black cattle. Mamm. Genome 14, 142-148 
Tholstrup T., Raff M., Basu S., Nonboe P., Sejrsen K., Straarup E.M., 2006. Effects of butter high in ruminant trans and monounsaturated fatty acids on lipoproteins, incorporation of fatty acids into lipid classes, plasma C-reactive protein, oxidative stress, hemostatic variables, and insulin in healthy young men. Amer. J. Clin. Nutr. 83, 237-243

Turpeinen A.M., Mutanen M., Aro A., Salminen I., Basu S., Palmquist D.L., Griinari J.M., 2002. Bioconversion of vaccenic acid to conjugated linoleic acid in humans. Amer. J. Clin. Nutr. 76, 504-510

Wahle K.W.J., Heys S.D., Rotondo D., 2004. Conjugated linoleic acids: are they beneficial or detrimental to health? Prog. Lipid Res. 43, 553-587

Wang Y., Jing L.J., Ruth M.R., Goruk S.D., Reaney M.J., Glimm D.R., Vine D.F., Field C.J., Proctor S. D., 2008. Trans-11 vaccenic acid dietary supplementation induces hypolipidemic effects in JCR:LA-cp rats. J. Nutr. 138, 2117-2122

Waters S. M., Kelly J. P., O’Boyle P., Moloney A. P., Kenny D. A., 2009. Effect of level and duration of dietary n-3 polyunsaturated fatty acid supplementation on the transcriptional regulation of $\Delta^{9}$-desaturase in muscle of beef cattle. J. Anim. Sci. 87, 244-252 